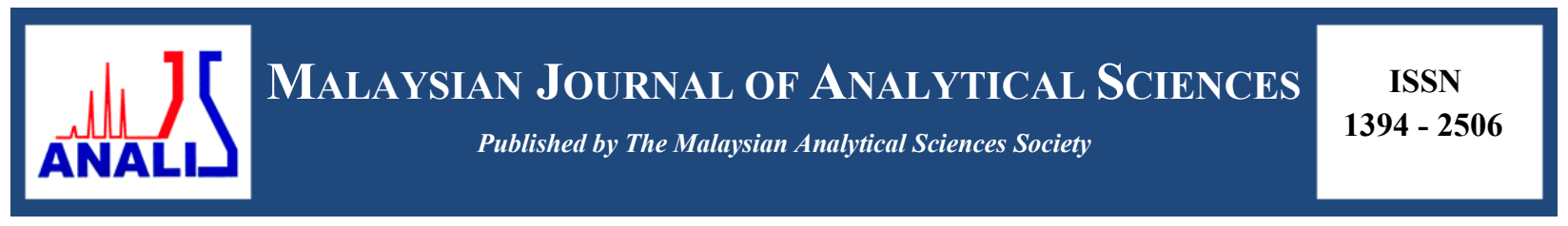

\title{
BIOACCUMULATION OF SEDIMENTARY ENDOCRINE DISRUPTING CHEMICALS (EDCs) BY THE BENTHIC FISH, Pleuronectes yokohamae
}

\author{
(Biopenumpukan Bahan Kimia Pengganggu Endokrin (EDCs) oleh Ikan Bentik, Pleuronectes \\ yokohamae)
}

\author{
Nurulnadia Mohd Yusoff ${ }^{1}$, Jiro Koyama ${ }^{2}$, Seiichi Uno ${ }^{2}$ \\ ${ }^{1}$ School of Marine and Environmental Sciences, \\ Universiti Malaysia Terengganu, 21030 Kuala Terengganu, Terengganu, Malaysia \\ ${ }^{2}$ Faculty of Fisheries, \\ Kagoshima University, Shimoarata 4-50-20, Kagoshima 890-0056, Japan
}

*Corresponding author: nurulnadia@umt.edu.my

Received: 16 August 2016; Accepted: 20 April 2017

\begin{abstract}
In this study, Pleuronectes yokohamae (P. yokohamae) were exposed to the sediment mixed with mixture of nonylphenol (NP), octylphenol (OP), estrone (E1) and 17ß-estradiol (E2) which makes up Endocrine Disrupting Chemicals (EDCs). The target compound was detected in water sample, and NP and OP concentrations were found to be the highest, $7.66 \mu \mathrm{g} / \mathrm{L}$ and $0.63 \mu \mathrm{g} / \mathrm{L}$ respectively (E1 and E2 concentrations were below the limit of detection). In pore water on the other hand, NP concentrations recorded the highest with $35.3 \mu \mathrm{g} / \mathrm{L}$, while concentrations of OP, E1 and E2 were $4.08 \mu \mathrm{g} / \mathrm{L}, 0.06 \mu \mathrm{g} / \mathrm{L}$ and $0.18 \mu \mathrm{g} / \mathrm{L}$ respectively. P. yokohamae shown rapid and maximum accumulation of NP and OP on day 3 , where NP recorded to be 2200 $\mathrm{ng} / \mathrm{g}$ d.w. and OP $168 \mathrm{ng} / \mathrm{g}$ d.w. The recorded BAF values in low and high exposure groups were 0.010 and 0.065 for NP, and 0.065 and 0.084 for OP. The BAF findings recorded, being less than 1 indicated that there were no bioaccumulations in the tested fish of both groups. However, due to their nature of being more predisposed to accumulating EDCs than the water column, the bioaccumulation of contaminant in benthic fish should be continually monitored.
\end{abstract}

Keywords: bioaccumulation, sediment, endocrine disrupting chemical, Pleuronectes yokohamae, marbled flounder

\begin{abstract}
Abstrak
Dalam kajian ini, campuran bahan kimia pengganggu endokrin (EDC) terdiri daripada nonilfenol (NP), oktilfenol (OP), estron (E1) dan 17ß-estradiol (E2) telah dicampur ke dalam sedimen dan didedahkan kepada Pleuronectes yokohamae (P. yokohamae). Sebatian sasaran telah dikesan dalam sampel air dengan kepekatan NP dan OP tertinggi iaitu masing-masing 7.66 $\mu \mathrm{g} / \mathrm{L}$ dan 0.63 $\mu \mathrm{g} / \mathrm{L}$ (kepekatan E1 dan E2 adalah di bawah had pengesanan), manakala kepekatan tertinggi di dalam air liang ialah $35.3 \mu \mathrm{g} / \mathrm{L}$ untuk NP, $4.08 \mu \mathrm{g} / \mathrm{L}$ untuk OP, $0.06 \mu \mathrm{g} / \mathrm{L}$ untuk E1 dan $0.18 \mu \mathrm{g} / \mathrm{L}$ untuk E2. Kepekatan NP dan OP di dalam P. yokohamae meningkat dengan mendadak pada hari 3 dan mencapai kepekatan maksimum 2200 ng/g d.w. dan 168 ng/g d.w. Nilai BAF dalam kumpulan kepekatan rendah dan tinggi ialah 0.010 dan 0.065 untuk NP, dan 0.065 dan 0.084 untuk OP. BAF telah dikira kurang daripada 1 menunjukkan tiada biopenumpukan EDC dalam ikan untuk kedua-dua kumpulan kepekatan. Walaupun begitu, biopenumpukan bahan cemar kepada ikan bentik harus sentiasa dipantau melalui sedimen berikutan kebolehannya menumpuk bahan EDC adalah lebih tinggi berbanding kolum air.
\end{abstract}

Kata kunci: biopenumpukan, sedimen, bahan kimia pengganggu endokrin, Pleuronectes yokohamae, marbled flounder 


\section{Introduction}

Endocrine Disrupting Chemicals (EDCs) are either estrogenic or natural - the estrogenic chemicals such as nonylphenol (NP), and octylphenol (OP) are mostly industrial byproduct of surfactants in detergents and paints, agricultural dispersing agents, and other industrial applications [1] while natural forms which include $17 \beta$-estradiol (E2) and estrone (E1) excreted by humans and livestock, are discharged from sewage treatment works and agricultural run-off into the aquatic ecosystems [2]. As a result, these compounds were frequently reported to disturb the reproductive system in fish such as reduced in testicular growth and formation of eggs in testis [3].

Endocrine disruption in fish occurs as a result of the binding of natural and manmade compounds in the aquatic environment to estrogen receptors, in place of endogenous hormone. The EDCs then alter the enzyme system controlling steroidogenesis, causing mimicking or blocking effects that disrupt normal endocrine pathways [4]. Researchers hypothesised that EDCs could be hydrophobic substances with affinity to bind to particles and accumulate on bottom sediments [5]. EDCs tend to get adsorbed into sediment due to high octanol-water partition coefficient (log Kow), resulting in vulnerability of aquatic organisms to accumulation [6].

P. yokohamae resides in sandy-mud bottoms less than $100 \mathrm{~m}$ depth [7] and recognised as commercially important species [8]. In Japan, winter is the breeding season of $P$. yokohamae. Both male and female fish reach maturity at the age of 1 year [9]. P. yokohamae prey mainly on benthic animals and were reported to accumulate organic compounds such as tributyltin (TBT) [10], 1,1-dichloro-2,2-bis(p-chlorophenyl) ethylene (DDE), hexachlorobenzene (HCB) and polychlorinated biphenyls (PCBs) [11] in the liver. Thus, P. yokohamae can serve as a good indicator of EDCs accumulation from sediment.

Bioaccumulation of EDCs has been demonstrated in both field and laboratory-based experiment [12, 13]. To date, nearly all experiments conducted on EDCs apply either the waterborne [14] or intraperitoneal exposure methods [15]. Very few studies adopted dietary and sedimentary exposure. Following this observation, this experiment aims to determine the bioaccumulation factor of EDCs through direct sedimentary uptake. Realising the significance of fisheries as an important commodity and main sources of diet for Japanese people, investigation on potential bioaccumulation of EDCs in fish is undeniably necessary.

\section{Test organism (P. yokohamae)}

\section{Materials and Methods}

P. yokohamae were purchased from Regional Government Aquaculture Center in Yamaguchi, Japan. They were acclimatized in the laboratory condition for six months to the desired body size and fed with commercial diet. $P$. yokohamae were kept in the water temperature below $25^{\circ} \mathrm{C}$ as it will die in warm water.

\section{Sampling of sediment}

Approximately ten kilograms of sediment were collected randomly around the Amori River mouth in Kagoshima Bay (Figure 1) on 24 October 2012. Upon arrival at the laboratory, all sediment samples were dried under the sunlight and at room temperature for one week. Prior to spiking with EDCs, the sediment samples were combined and mixed well after sieving using sized 1- mm mesh sieve.

\section{Preparation of EDCs spiked sediment}

Three kilograms of the sieved sediment were transferred into each glass aquarium $(60 \times 30 \times 40 \mathrm{~cm})$ of control, low and high test groups. The mixture of EDCs was then prepared according to Table 1. 


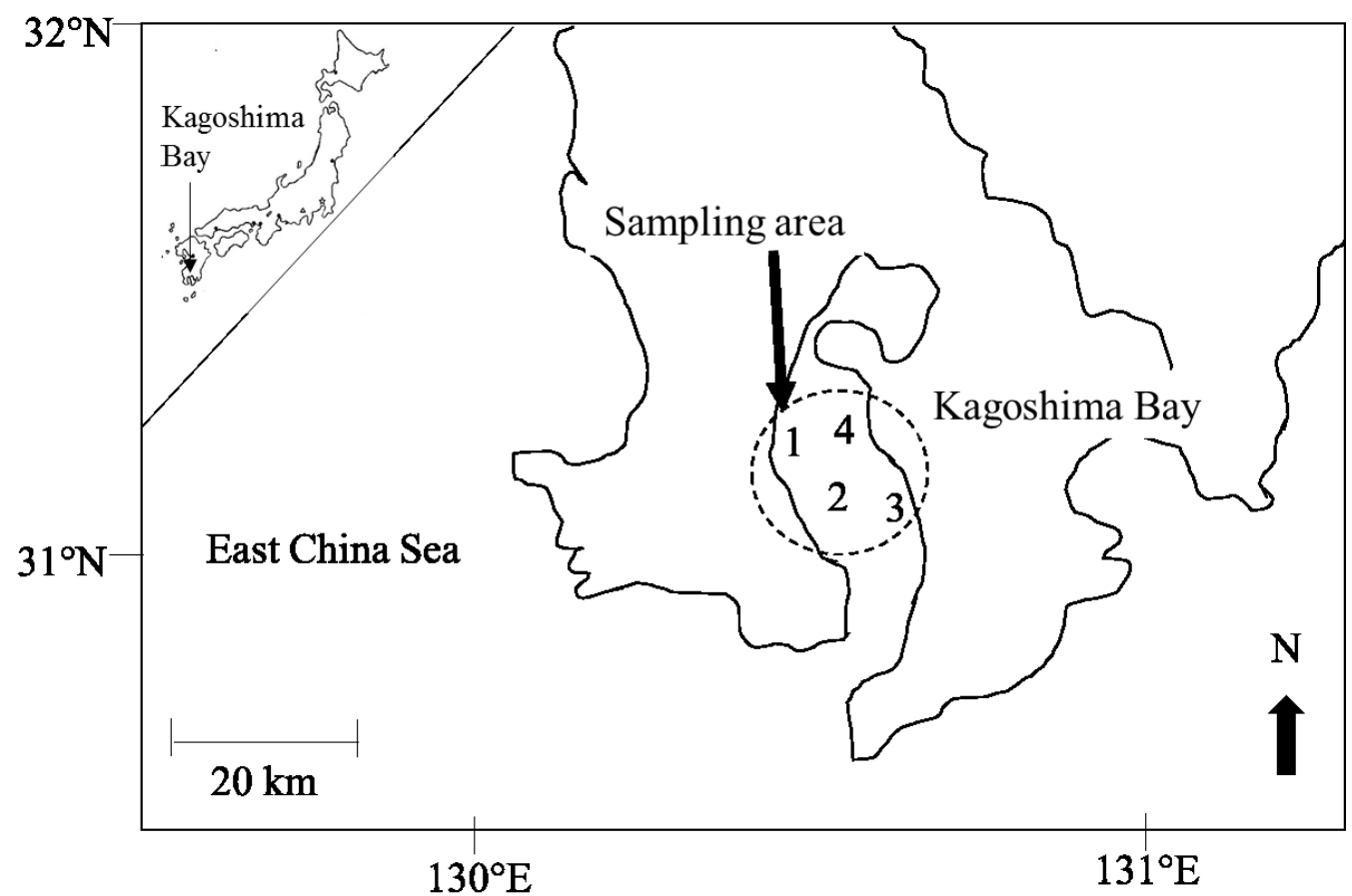

Figure 1. Sediment sampling stations (1, 2, 3 and 4) located in Kagoshima Bay

Table 1. Mean EDCs concentration, ng/g dry weight (d.w.) in control and spiked sediment, $\mathrm{n}=2$

\begin{tabular}{lccc}
\hline \multirow{2}{*}{ EDCs } & \multicolumn{3}{c}{ ng/g dry weight (d.w.) } \\
\cline { 2 - 4 } & Control & Low & High \\
\hline NP & 5.09 & 2750 & 30,400 \\
OP & 0.63 & 169 & 1,210 \\
E1 & 2.36 & 1.90 & 10.8 \\
E2 & n.d & 0.83 & 6.70 \\
\hline
\end{tabular}

n.d - Not detected

\section{Exposure scheme}

Before introducing $P$. yokohamae, the sediment in each aquarium $(60 \times 30 \times 40 \mathrm{~cm})$ was flooded and inundated with $60 \mathrm{~L}$ of seawater for a week. This condition was maintained in a water-flow-through system. After one week, fifteen of $P$. yokohamae were introduced into each aquarium including the control group. They were fed ad libitum with commercial fish diet twice daily for 14 days of the experimental duration. Sampling of P. yokohamae were done on days $0,3,7$ and 14 while water sampling was done on days $4,8,10$ and 13. At the end of exposure, sediment and pore-water samples were gathered. The body weight of individual $P$. yokohamae at the initial of exposure ranged from $7.30 \mathrm{~g}$ and $8.70 \mathrm{~g}$. During sampling, P. yokohamae were anaesthetized using $0.05 \%$ 2-phenoxyethanol. The body length and weight were recorded prior to storage of the samples in freezer $\left(-18{ }^{\circ} \mathrm{C}\right)$ until analysis stage. Water parameters such as temperature, dissolved oxygen, $\mathrm{pH}$ and salinity were measured periodically using the YSI multiprobe meter. 


\section{Pre-treatment of samples}

After thawing, each benthic fish was weighed into a glass bottle to record the wet weight. The fishes were then freeze dried at $-48{ }^{\circ} \mathrm{C}$ and $7.8 \mathrm{~Pa}$ for 7 days, and immediately after that, the dry weights of fishes were recorded. Sediment samples were treated the same way as benthic fishes. Wet and dry weights of sediments were recorded before and after freeze drying process. Water and pore water samples were analysed on the day of collection.

\section{EDCs analysis}

EDCs were analysed according to the published procedures in Nurulnadia [16]. After addition of external standard of $p$-n-NP-d4, target chemicals in the freeze-dried benthic fish (weights of homogenate sample ranged from 0.78 to $3.05 \mathrm{~g})$ were ultrasonically extracted twice with $20 \mathrm{~mL}$ of methanol for 15 minutes. After centrifugation $\left(4{ }^{\circ} \mathrm{C}, 760\right.$ $\mathrm{x} \mathrm{g}, 10$ minutes), the organic layer was collected and transferred into a separating funnel. Later, $3 \mathrm{~mL}$ Milli-Q water and $3 \mathrm{~mL}$ hexane were added. As lipid interfere with the measurement, they were removed from methanol using 20 $\mathrm{mL}$ hexane with 5 minutes shaking. This step was repeated three times. After shaking, hexane layer was discarded, while methanol (denser than hexane) was collected and combined. Methanol was put into the separating funnel again and mixed with $50 \mathrm{~mL}$ of $5 \%$ sodium chloride $(\mathrm{NaCl})$ and $0.2 \mathrm{~mL}$ concentrated hydrochloric acid. The mixture of solvents was extracted twice using $20 \mathrm{~mL}$ dichloromethane and 10 min shaking and concentrated to 0.5 $\mathrm{mL}$ using a rotary evaporator and gentle stream of nitrogen $\left(\mathrm{N}_{2}\right)$. The concentrated extract was then replaced with 3 $\mathrm{mL}$ hexane and concentrated again to $0.5 \mathrm{~mL}$ using $\mathrm{N}_{2}$. This step was repeated three times. Cleaning up process was performed in a $5 \mathrm{~mL}$ glass pipette $(6 \mathrm{~mm}$ i.d. $\mathrm{x} 17 \mathrm{~cm}$ ) filled with florisil (containing $3 \%$ water) and prewashed with $30 \mathrm{~mL}$ hexane. The target chemicals were then eluted with $50 \mathrm{~mL}$ hexane-isopropyl alcohol $(9: 1, \mathrm{v} / \mathrm{v})$. The eluate was later concentrated to dryness using a rotary evaporator and gentle stream of $\mathrm{N}_{2}$. Finally, internal standard (E2$16,16,17-\mathrm{d} 3$ ) and acetonitrile were added to achieve the final volume of $0.2 \mathrm{~mL}$ before liquid chromatographytandem mass spectrometry (LC-MS/MS) measurement.

Similar procedures were applied for sediment, water and diet samples.

\section{Measurement using LC-MS/MS-ESI}

LC-MS/MS analysis was carried out using Agilent 1200 LC system (Agilent Technologies, USA) coupled to an API-2000 triple stage quadruple mass spectrometer (Applied Biosystems, USA). The ESI was employed in negative mode. The optimized parameters were set as follows: curtain gas (40 psi), turbo gas ( $80 \mathrm{psi})$ and auxiliary gases ( 80 psi) using nitrogen, CAD gas, $5 \mathrm{psi}$; ion spray voltage, $-4,500 \mathrm{~V}$; and turbo temperature, $400^{\circ} \mathrm{C}$. $\mathrm{MS} / \mathrm{MS}$ measurements were performed in multiple reactions monitoring mode and target chemicals were four EDC compounds as shown in Table 2. The EDCs were analysed by gradient liquid chromatography using a reverse-phase Extend C-18 column $\left(2.1 \mathrm{~mm}\right.$ i.d. $9100 \mathrm{~mm}, 3.5 \mu \mathrm{m}$ of particle size, Agilent) kept at $40{ }^{\circ} \mathrm{C}$. The mobile phase consisted of solvents $\mathrm{A}(100 \%$ acetonitrile) and B (water containing $0.1 \%$ triethylamine, $(\mathrm{v} / \mathrm{v}))$.

Quality assurance test was performed using fish diet spiked with $100 \mathrm{ng} / \mathrm{g}$ of each EDC standards and internal standard (E2-16,16,17-d3). The EDCs standard extraction and measurement were done as above procedures. Mean percent recovery, as determined from an estimate of the amount of added and recovered, were between $70.0 \%$ and $102.3 \%$. Analysis were conducted in triplicate $(\mathrm{n}=3)$ with error of all analysis were within $\pm 20 \%$.

Table 2. Precursor and daughter ions of EDCs and limit of detection by LC-MS/MS-ESI

\begin{tabular}{|c|c|c|c|c|}
\hline \multirow[t]{2}{*}{ EDCs } & \multirow{2}{*}{$\begin{array}{l}\text { Precursor Ions, } \\
\text { m/z (amu) }\end{array}$} & \multirow{2}{*}{$\begin{array}{l}\text { Daughter Ions, } \\
\text { m/z (amu) }\end{array}$} & \multicolumn{2}{|c|}{ Limit of Detection (ng/g) } \\
\hline & & & $\begin{array}{c}\text { Diet } \\
(\mathbf{n g} / \mathbf{g})^{\mathrm{a}}\end{array}$ & $\begin{array}{l}\text { Water } \\
(\mu \mathrm{g} / \mathrm{L})^{\mathrm{b}}\end{array}$ \\
\hline NP & 219.0 & 132.9 & 2.67 & 0.54 \\
\hline $\mathrm{OP}$ & 205.0 & 132.9 & 0.31 & 0.05 \\
\hline E1 & 269.1 & 145.0 & 1.01 & 0.05 \\
\hline E2 & 271.1 & 144.9 & 1.50 & 0.10 \\
\hline
\end{tabular}

${ }^{\mathrm{a}}$ Detection limit using $0.3 \mathrm{~g}$ diet sample; ${ }^{\mathrm{b}}$ Detection limit using $0.5 \mathrm{~L}$ seawater 


\section{Data analysis}

BAF (bioaccumulation factors) were calculated as the ratio of concentration in biota to sediment $[17,18]$ using the formula stated below:

$$
\mathrm{BAF}=\frac{(\text { EDCs concentration at steady state in } P . \text { yokohamae })}{(\text { EDCs concentration in sediment })}
$$

\section{Water parameters and control sediment}

\section{Results and Discussion}

In the present study, range of water temperature and dissolved oxygen were 12.8 to $14.6{ }^{\circ} \mathrm{C}$ and 5.93 to $8.48 \mathrm{mg} / \mathrm{L}$ respectively, whereas $\mathrm{pH}$ and salinity were 8.01 to 8.08 and 36 to 38 psu respectively. Sediment sample collected from Amori River contains three of the target EDCs as shown in Table 1 (control). Amori River is one of the longest (42.5 km long) river, flowing into Kagoshima Bay, hence it receives large amount of effluent from residential and municipal activities daily. This most likely contributed to some concentrations of NP, OP and E1 in the control sediment. The total organic carbon and total organic nitrogen in sediment were $1.43 \pm 0.0 .6 \%$ and $0.11 \pm 0.004 \%(\mathrm{n}=5)$ respectively.

The concentration of EDCs was measured in the water sample during the exposure test, showing a range of 0.85 and $7.66 \mu \mathrm{g} / \mathrm{L}$ for NP, and $0.49 \mu \mathrm{g} / \mathrm{L}$ and $0.63 \mu \mathrm{g} / \mathrm{L}$ for OP, respectively whereas E1 and E2 concentrations were below the limit of detection. Low concentrations of EDCs were expected to be released into the water as P. yokohamae dwell onto the sediment. Low concentrations of EDCs were also recorded in pore water collected right after the exposure period ended (Table 3). In laboratory controlled uptake studies for NP, Bioconcentration factors (BCFs) yielded ranged from 200 to $300[19,20]$ whereas, OP were recorded to be from 250 to 350 [21, 22]. If $P$. yokohamae in this study has bio accumulated the target compound from water, the estimated concentration of NP and OP from maximum value would be approximately 2,300 and $221 \mathrm{ng} / \mathrm{g}$ w.w., respectively. However, the maximum wet weight concentrations of NP (532 ng/g w.w.) and OP (45.4 ng/g w.w.) in P. yokohamae in this study were recorded much lower than those estimated concentration. Thus, it was assumed that P. yokohamae in the present study accumulated EDCs from the spiked sediment.

Table 3. EDCs concentration $(\mu \mathrm{g} / \mathrm{L})$ in pore water, $\mathrm{n}=2$

\begin{tabular}{lcccc}
\hline Exposure Group & NP & OP & E1 & E2 \\
\hline Control & 16.9 & n.d & n.d & n.d \\
Low & 11.7 & 0.15 & n.d & n.d \\
High & 35.3 & 4.08 & 0.06 & 0.18 \\
\hline
\end{tabular}

n.d - Not detected

\section{NP and OP concentrations in P. yokohamae}

As reported in previous study [23], E1 and E2 could not be detected in P. yokohamae due to rapid metabolism of the substance in the fish. The accumulation of NP and OP in P. yokohamae from the sediment is shown in Figure 2. The concentration is calculated in dry weight (d.w.) basis to ease the determination of bioaccumulation factor (BAF). On day 0, NP and OP were detected in P. yokohamae with $114 \pm 91$ and $34.4 \pm 15 \mathrm{ng} / \mathrm{g}$ d.w., respectively. Both compounds probably accumulated from commercial diet fed during the acclimatization period [24] as they were measured $27.9 \pm 1.77 \mathrm{ng} / \mathrm{g}$ d.w of NP and $3.02 \pm 0.34 \mathrm{ng} / \mathrm{g}$ d.w of OP in the control diet. P. yokohamae rapidly accumulated NP and OP on day 3 of exposure period and reached the maximum concentration. The highest concentration of NP in low and high exposure groups were 249 and $2200 \mathrm{ng} / \mathrm{g} \mathrm{d}$.w. respectively, whereas the recorded OP concentrations were 56.3 and $168 \mathrm{ng} / \mathrm{g}$ d.w. respectively. After day 3, observations shown that the 
concentrations declined consistently until the end of experiment. Hence, day 3 was decided as the point at which steady state was reached for both NP and OP and these concentrations were used for the BAF computation.

\section{Bioaccumulation factors (BAF)}

BAFs were calculated using the concentration of NP and OP at day 3 of each group relative to measured concentration of the respective compound in the spiked sediment (Table 4). BAF values were similar between the low and high exposure groups indicating that the difference in concentration does not affect the bioaccumulation. However, NP and OP were not bio accumulated in P. yokohamae as the BAF values less than 1 [23].

Table 4. BAF in low and high exposure groups

\begin{tabular}{lcc}
\hline EDCs & Low & High \\
\hline NP & 0.010 & 0.065 \\
OP & 0.065 & 0.084 \\
\hline
\end{tabular}
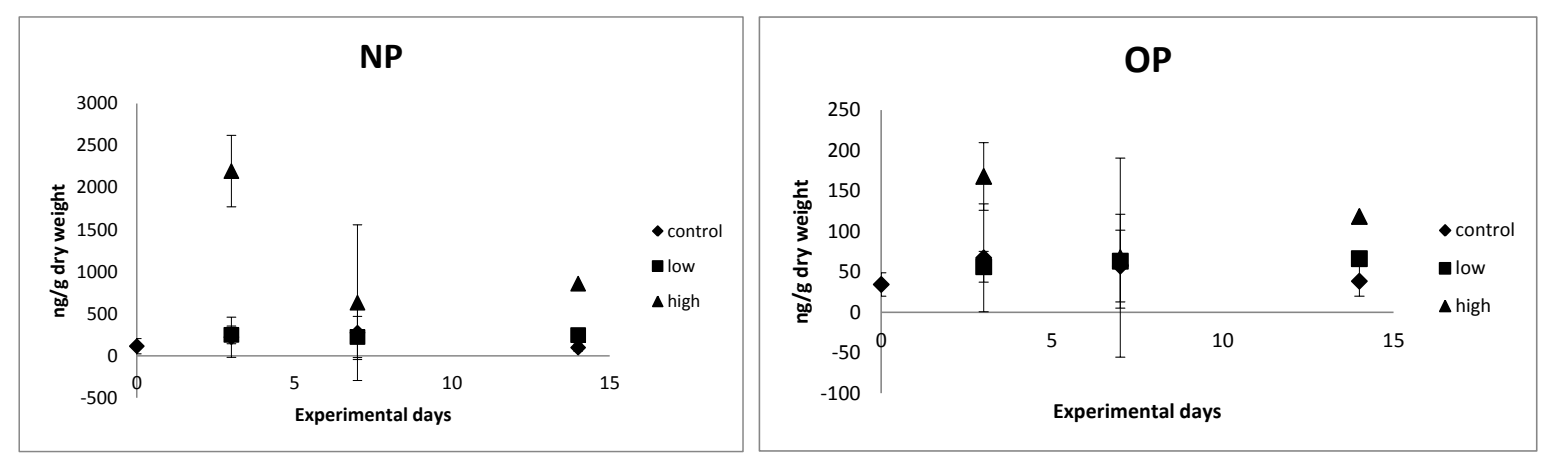

Figure 2. Accumulation of NP and OP (ng/g dry weight) in P. yokohamae in control, low and high exposure groups. Error bars indicate the standard deviation $(\mathrm{n}=3)$

BAF from previous studies are tabulated in Table 5. Based on the values, NP was discovered to be bio accumulated in bluegill, flounder and goby with BAF of 2.33, 6.24 and 27.0, respectively. These fishes were collected near sewage treatment water effluent; thus, it was probable that they may have accumulated NP from the water as well. $\mathrm{NP}$ was also found to be bioaccumulated in worm, mussel and bivalve. As sediment-dwelling organism, worms are in direct exposure to the pollutant in sediment - which may cause bioaccumulation [25]; higher concentration of NP in benthic worm compared to sediment was also observed in our previous field study [26]. Meanwhile, mussel and bivalve were sampled in urban and industrial areas [16,27], hence received NP at frequent term which could lead to bioaccumulation. However, many other studies reported the same results as the present study that NP was not bioaccumulated in fish. In the case of OP on the other hand, no bioaccumulation was observed either in fish or invertebrate.

NP and OP did not bioaccumulate in P. yokohamae through the sediment as suggested by BAF values. However, certain aquatic organisms could probably accumulate EDCs (e.g. bluegill, flounder, and goby). This provides an impression that accumulation is probably influenced by species specific. This study was conducted to investigate the extremely high BAF values of EDCs measured in benthic worm compared to sediment samples of Osaka Bay [16]. If the worm accumulated EDCs from the sediment, the fish might accumulate the same compounds. Following this hypothesis, the EDCs have great potentials to be transferred into human as they consume the fish. Therefore, the EDCs measurement in fish from Osaka Bay should be conducted in order to prove the hypothesis. 
Table 5. Bioaccumulation factors (BAF) of NP and OP in fishes and invertebrates

\begin{tabular}{lccll}
\hline & \multicolumn{2}{c}{ BAF } & Study Area & Reference \\
\cline { 2 - 4 } Fish & NP & OP & & \\
Bluegill & & & & {$[28]$} \\
Flounder & 2.330 & n.a & Kalamazoo River, US & {$[29]$} \\
& 6.240 & n.a & Tyne Estuary, UK & \\
Various fish & 0.042 & 0.960 & Tees Estuary, UK & {$[30]$} \\
Flatfish & 0.208 & 0.121 & Ebro river basin, Spain & {$[31]$} \\
Black seabream & 0.981 & n.a & Southern California Bight & {$[32]$} \\
Yellowfin seabream & 0.013 & 0.009 & Yundang Lagoon, China & \\
Tilapia & 0.082 & 0.014 & & \\
Goby & 0.303 & 0.073 & & Present study \\
Sole & 27.00 & n.a & North American Pacific Coast estuaries & {$[12]$} \\
(P. yokohamae) & $\mathbf{0 . 0 3 8}$ & $\mathbf{0 . 0 7 5}$ & Lab exposure & \\
Invertebrate & & & & {$[33]$} \\
Shrimp & & & & {$[34]$} \\
Bivalve & 0.002 & n.a & Scheldt estuary, The Netherlands & {$[26]$} \\
Worm & 6.580 & n.a & Northeast coast of China & {$[32]$} \\
Short-necked clam & 5.900 & n.a & Lab exposure & {$[27]$} \\
Mussel & 0.065 & 0.042 & Yundang Lagoon, China & \\
\hline
\end{tabular}

\section{Conclusion}

P. yokohamae in this study rapidly accumulated NP and OP from the sediment until day 3 . After that the concentrations of both EDCs decreased to constant level until the end of experiment. E1 and E2 could not be detected in P. yokohamae due to rapid metabolism which were proven in our recent study [23]. BAF values for both compounds (NP and OP) indicated bioaccumulation did not occur in P. yokohamae after being exposed to EDCs spiked sediment. However, bioaccumulation of EDCs to benthic organism should be continually investigated as sediment can concentrate higher levels of pollutant than the water column.

\section{Acknowledgement}

The present study was partly funded by the EXTEND 2010 Program, Ministry of Environment, Japan.

\section{References}

1. Folmar, L. C., Denslow, N. D., Kroll, K., Orlando, E. F., Enblom, J., Marcino, J., Metcalfe, C. and Guillette Jr., L. J. (2001). Altered serum sex steroids and vitellogenin induction in walleye (Stizostedion vitreum) collected near a metropolitan sewage treatment plant. Archives of Environmental Contamination \& Toxicology, 40: 392 398.

2. Tashiro, Y., Takemura, A., Fujii, H., Takahira, K. and Nakanishi, Y. (2003). Livestock wastes as a source of estrogens and their effects on wildlife of Manko tidal flat, Okinawa. Marine Pollution Bulletin, 47: 143 - 147.

3. Gray, M. A. and Metcalfe, C. D. (1997). Induction of testis-ova in Japanese medaka (Oryzias latipes) exposed to p-nonylphenol. Environmental Toxicology \& Chemistry, 16(5): 1082 - 1086. 
4. Tapiero, H., Nguyen, Ba G. and Tew K. D. (2002). Estrogens and environmental estrogens. Biomedicine \& Pharmacotherapy, 56: $36-44$.

5. Yu, Z. Q., Xiao, B. H., Huang,W. L. and Peng, P. (2004). Sorption of steroid estrogens to soils and sediments. Environmental Toxicology and Chemistry, 23: $531-539$.

6. David, A., Fenet, H. and Gomez, E. (2009). Alkylphenols in marine environments: distribution monitoring strategies and detection considerations. Marine Pollution Bulletin, 58: 953 - 960.

7. Sakamoto, K. (1984). Pleuronectidae righteye flounders. In H. Masuda, K. Amaoka, T. Araga, T. Ueno, \& T. Yoshino (Eds.). The Fishes of the Japanese Archipelago Tokyo: Tokai University Press: pp. 336 - 340.

8. Park, J. S. (1988). A study on the pleuronectid flounder Limanda yokohamae population in Tokyo Bay. PhD Thesis, University of Tokyo, Tokyo (in Japanese).

9. Park, J. S. and Simizu, M. (1990). Maturity and spawning season of the Limanda yokohamae (Günther) in Tokyo Bay, Japan. Bulletin of Fisheries Science Institute, 6, 1 - 6.

10. Takayama, T., Hashimoto, S., Tokai, T. and Otsuki, A. (1995). Measurements of organic tin compounds in fish and crustacean of Tokyo Bay. Environmental Science, 8: 1 - 9.

11. Kammann, U., Landgraff, O. and Steinhart, H. (1993). Distribution of aromatic organochlorines in livers and reproductive organs of male and female dabs from the German Bight. Marine Pollution Bulletin, 26: 629 - 635 .

12. Diehl, J., Johnson, S. E., Xia, K., West, A. and Tomanek, L. (2012). The distribution of 4 nonylphenol in marine organisms of North American Pacific Coast estuaries. Chemosphere, 87(5): 490 - 497.

13. Liber, K., Gangl, J. A., Corry, T. D., Heinis, L. J. and Stay, F. S. (1999). Lethality and bioaccumulation of 4nonylphenol in bluegill sunfish in littoral enclosures. Environmental Toxicology \& Chemistry, 18: 394 - 400.

14. Thorpe, K. L., Hutchinson, T. H., Hetheridge, M. J., Scholze, M., Sumpter, J. P. and Tyler, C. R. (2001). Assessing the biological potency of binary mixtures of environmental estrogens using vitellogenin induction in juvenile rainbow trout (Oncorhynchus mykiss). Environmental Science \& Technology, 35(12): 2476 - 2481.

15. Arukwe, A., Thibaut, R., Ingebrigsten, K., Celius, T., Goksøyr, A. and Cravedi, J. P. (2000). In vivo and in vitro metabolism and organ distribution of nonylphenol in Atlantic salmon (Salmo salar). Aquatic Toxicology, 49(4): $289-304$.

16. Nurulnadia, M. Y., Koyama, J., Uno, S., Kito, A., Kokushi, E., Bacolod, E. T., Ito, K. and Chuman, Y. (2014). Accumulation of endocrine disrupting chemicals (EDCs) in the polychaete Paraprionospio sp. from the Yodo River mouth, Osaka Bay, Japan. Environmental Monitoring \& Assessment, 186(3): 1453 - 1463.

17. Kwok, C. K., Liang, Y., Leung, S. Y., Wang, H., Dong, Y. H., Young, L., Giesy, J. P. and Wong, M. H. (2013). Biota-sediment accumulation factor (BSAF), bioaccumulation factor (BAF), and contaminant levels in prey fish to indicate the extent of PAHs and OCPs contamination in eggs of waterbirds. Environmental Science \& Pollution Research, 20(12): 8425 - 8434.

18. Melwani, A. R., Greenfield, B. K. and Byron, E. R. (2009). Empirical estimation of biota exposure range for calculation of bioaccumulation parameters. Integrated Environmental Assessment \& Management, 5(1): 138 149.

19. Servos, M. R. (1999). Review of the aquatic toxicity, estrogenic responses and bioaccumulation of alkylphenols and alkylphenol polyethoxylates. Water Quality Research Journal of Canada, 34: 123 -177.

20. Staples, C., Mihaich, E., Carbone, J., Woodburn, K. and Klecka, G. (2004). A weight of evidence analysis of the chronic ecotoxicity of nonylpenol ethoxylates, nonylphenol ether carboxylates, and nonylphenol. Human \& Ecological Risk Assessment, 10: 999 - 1017.

21. Ferreira-Leach, A. M. R. amd Hill, E. M. (2000). Bioconcentration and metabolism of 4-tert octylphenol in roach (Rutilus rutilus) fry. Analysis, 28(9): $789-792$.

22. Tsuda, T., Takino, A., Muraki, K., Harada, H. and Kojima, M. (2001). Evaluation of 4 nonylphenols and 4-tertoctylphenol contamination of fish in rivers by laboratory accumulation and excretion experiments. Water Research, 35(7): $1786-1792$.

23. Nurulnadia, M. Y., Koyama, J., Uno, S. and Amano, H. (2016). Biomagnification of endocrine disrupting chemicals (EDCs) by Pleuronectes yokohamae: Does P. yokohamae accumulate dietary EDCs?. Chemosphere, 144: $185-192$.

24. Nurulnadia, M. Y., Koyama, J., Uno, S., Kokushi, E., Bacolod, E. T., Ito, K. and Chuman, Y. (2013). Bioaccumulation of dietary Endocrine Disrupting Chemicals (EDCs) by the Polychaete, Perinereisnuntia. Bulletin of Environmental Contamination \& Toxicology, 91(4): 372 - 376. 
25. Mitchelmore, C. L. and Rice, C. P. (2006). Correlations of nonylphenol-ethoxylates and nonylphenol with biomarkers of reproductive function in carp (Cyprinus carpio) from the Cuyahoga River. Science of The Total Environment, 371(1): $391-401$.

26. Mäenpää, K. and Kukkonen, J. V. K. (2006). Bioaccumulation and toxicity of 4-nonylphenol (4-NP) and 4-(2dodecyl)-benzene sulfonate (LAS) in Lumbriculus variegatus (Oligochaeta) and Chironomus riparius (Insecta). Aquatic Toxicology, 77(3): $329-338$.

27. Pojana, G., Gomiero, A., Jonkers, N. and Marcomini, A. (2007). Natural and synthetic endocrine disrupting compounds (EDCs) in water, sediment and biota of a coastal lagoon. Environment International, 33(7): 929 936.

28. Kannan, K., Keith, T. L., Naylor, C. G., Staples, C. A., Snyder, S. A. and Giesy, J. P. (2003). Nonylphenol and nonylphenol ethoxylates in fish, sediment, and water from the Kalamazoo River, Michigan. Archives of Environmental Contamination \& Toxicology, 44(1): $77-82$.

29. Lye, C. M., Frid, C. L. J., Gill, M. E., Cooper, D. W. and Jones, D. M. (1999). Estrogenic alkylphenols in fish tissues, sediments, and waters from the UK Tyne and Tees estuaries. Environmental Science \& Technology, 33(7): $1009-1014$.

30. Lacorte, S., Raldúa, D., Martínez, E., Navarro, A., Diez, S., Bayona, J. M. and Barceló, D. (2006). Pilot survey of a broad range of priority pollutants in sediment and fish from the Ebro river basin (NE Spain). Environmental Pollution, 140(3): $471-482$.

31. Maruya, K. A., Vidal-Dorsch, D. E., Bay, S. M., Kwon, J. W., Xia, K. and Armbrust, K. L. (2012). Organic contaminants of emerging concern in sediments and flatfish collected near outfalls discharging treated wastewater effluent to the Southern California Bight. Environmental Toxicology \& Chemistry, 31(12): 2683 2688.

32. Zhang, X., Gao, Y., Li, Q., Li, G., Guo, Q. and Yan, C. (2011). Estrogenic compounds and estrogenicity in surface water, sediments, and organisms from Yundang Lagoon in Xiamen, China. Archives of Environmental Contamination \& Toxicology, 61(1): $93-100$.

33. Verslycke, T. A., Vethaak, A. D., Arijs, K. and Janssen, C. R. (2005). Flame retardants, surfactants and organotins in sediment and mysid shrimp of the Scheldt estuary (The Netherlands). Environmental Pollution, 136(1): $19-31$.

34. Wang, J., Shim, W. J., Yim, U. H., Kannan, N. and Li, D. (2010). Nonylphenol in bivalves and sediments in the northeast coast of China. Journal of Environmental Sciences, 22(11): 1735 - 1740. 